\title{
PCR detection of Toxoplasma gondii $B 1$ gene in women suffering from abortion
}

\author{
Aseel S. Mahmood Sabeeha A. Al- Sarray Abdul-Kareem A. Al-Kazaz \\ Biotechnology Department / College of Science / University of Baghdad \\ E-mail : aseel78nm@yahoo.com
}

\begin{abstract}
Background: Primary infection of maternal with toxoplasmosis during gestation and this infection transmission to the fetus continue to be the cause complex disease in offspring.

Objective: This study was conducted to test the utility of nested Polymerase Chain Reaction (nPCR) assay to detect recent infections with Toxoplasma in abortive women.

Material and methods: Toxoplasma gondii DNA was detected by using B1 gene as a target for amplification which was highly specific for $T$. gondii and is well conserved among all of the tested strains. Blood from 60 abortive women and 25 apparently healthy pregnant women with no history of abortion (as control group) were taken in this current study.

Results: The results revealed that $\mathrm{nPCR}$ was positive in $48(80 \%)$ subjects and negative in $12(20 \%)$, Chi-square- $\chi^{2}$ for patients and control was $(13.82,15.75)$ respectively.

Conclusion: It can be concluded that $\mathrm{nPCR}$ assay in blood has advantage in detection of recent and active toxoplasmosis.
\end{abstract}

Keywords: Toxoplasma gondii , B1 gene, nested PCR.

\section{Introduction}

The toxoplasma gondii, is an obligated intracellular parasite, It can infect humans and several vertebrates leading to toxoplasmosis. This mostly benign affection cause severe life-threatening disease, immunocompromised particularly in patients and congenitally affected children $(1,2)$.

Infection of healthy adults $T$. gondii is asymptomatic in most cases. Function of Immune system shall prevent parasite replication and destroy any bradyzoites that are dormant tissue released cysts. However, tachyzoites can cross the placenta if a woman is infected during pregnancy this lead fetus infect (2). The infection course and symptoms are depend on many factors inclusive inoculation factors, particular organism virulence, gestational age at time of infection, genetic factors, and immune status of the mother and fetus (3).

Serological diagnosis act as most widely used approach to know the infection stage, whether current, recent or past (4). In spite of its high sensitivity these tests can supply vague results. For a definitive diagnosis direct detection of the parasite is necessary. Several PCR based assay have been developed for the detection of Toxoplasma DNA with $B 1$ repetive sequence which has been proven to be more sensitive when compared to other target e.g. $P 30$ gene and rDNA (5). This is probably because $B 1$ is repeated DNA sequence with a higher copy number than the single - copy $P 30$ gene (6). The $B 1$ gene is a 35 -fold repetitive gene sequence with unknown function, PCR amplifying this target has shown high specificity for DNA detection (7).

\section{Materials and Methods}

This study was carried out on 60 abortive Iraqi women and 25 control group of apparently healthy pregnant woman in ranged age between 18- 34 years. Samples were obtained from subjects in two hospitals included, AL- ALwia and Eben AL Balady.

\section{Blood samples and isolation of DNA}

Five ml was obtained of venous blood sample from each patient and control subjects in EDTA tube and stored at $-20^{\circ} \mathrm{C}$ until DNA extraction. DNA extraction from blood than stored at $-20^{\circ} \mathrm{C}$ until used by AccuPrep ${ }^{\circledR}$ Genomic DNA Extraction Kit Bioneer. 


\section{Nested PCR assay}

Nested PCR was complete all DNA samples to amplify a fragment from the $B 1$ gene, which is present in 35 copies and is conserved in the $T$. gondii genome, as described by (8). The primers used in the first round of the PCR (inner primers) were (5'-GGAACTGCATCCGTTCATGAG-3') and (5'TCTTTAAAGCGTTCGTGGTC- 3'), which correspond to nucleotides 694-714 and 887-868, respectively at $193 \mathrm{bp}$. Then primers used in the second round (outer primers) were (5'TGCATAGGTTGCAGTCACTG-3') and (5'-GGCGACCAATGTGCGAATAGACC-3'), which correspond to nucleotides 757-776 and 853-831, respectively at $96 \mathrm{bp}$. The $5 \mu \mathrm{L}$ of DNA template were added to a final volume of $20 \mu \mathrm{L}$ of PCR and mixture consisting of master mix , Then $1 \mu \mathrm{L}$ forward and reverse primers in concentration $(10 \mathrm{pmol})$, and $13 \mu \mathrm{L}$ of nuclease-free water added. Then amplification in the thermal cycler PCR shows in Table (1).

Table (1): PCR program

\begin{tabular}{|c|c|c|c|}
\hline Steps & Temperature & Time & Cycles \\
\hline - Initial Denaturation & $94^{\circ} \mathrm{C}$ & 3 minutes & 1 \\
\hline - Denaturation & $94^{\circ} \mathrm{C}$ & 30 seconds & \\
\hline - Annealing & $50^{\circ} \mathrm{C}$ & 45 seconds & 40 \\
\hline - Extension & $7^{\circ} \mathrm{C}$ & 1 minutes & \\
\hline - $\quad$ Final extention & $72^{\circ} \mathrm{C}$ & 10 minutes & 1 \\
\hline - Holding & $4^{\circ} \mathrm{C}$ & & \\
\hline
\end{tabular}

The PCR product were used for electrophoresis is $10 \mu \mathrm{L}$ on $2 \%$ gm agarose gel and detect 193 fragment of $\mathrm{B} 1$ gene. five $\mu \mathrm{L}$ from PCR product was used as template was used to the second run PCR in a total volume of $20 \mu \mathrm{L}$ of PCR mixture consisting of master mix , $1 \mu \mathrm{L}$ of Forword 2 and Reverse 2 in the concentration 10 pmol from each primer, completed by $11 \mu \mathrm{L}$ of nuclease-free water . Conditions of PCR second run were temperature $94^{\circ} \mathrm{C}$ at 3 minutes, 40 cycles at $94^{\circ} \mathrm{C}$ at 30 seconds, $50^{\circ} \mathrm{C}$ at 45 seconds and $72^{\circ} \mathrm{C}$ at 45 seconds and final extension at $72^{\circ} \mathrm{C}$ for 10 minutes. A $10 \mu \mathrm{L}$ from PCR product was used into electrophoresis in $2.5 \%$ agarose gel stained by ethidium bromide to detect 96 fragment of B1 gene.

\section{Result and Discussion}

A parasite DNA disclosure by PCR has extremely amended diagnosis, especially in prenatal diagnosis to congenital disease (9).

A results are depend on amplification two DNA fragments (193 bp and 96 bp) of $B 1$ gene by Analysis of nPCR in infected women blood sample. The consequence have showed that clear band of DNA fragment of PCR product these signal a presence of $B 1$ gene in $49(81 \%)$ with highly significant difference and that clarified the existence of infection, while 11(19\%) showed absence of amplified DNA fragment indicated that not found the $B 1$ gene no infection Figure (1) and Figure (2) as well as Table (2).

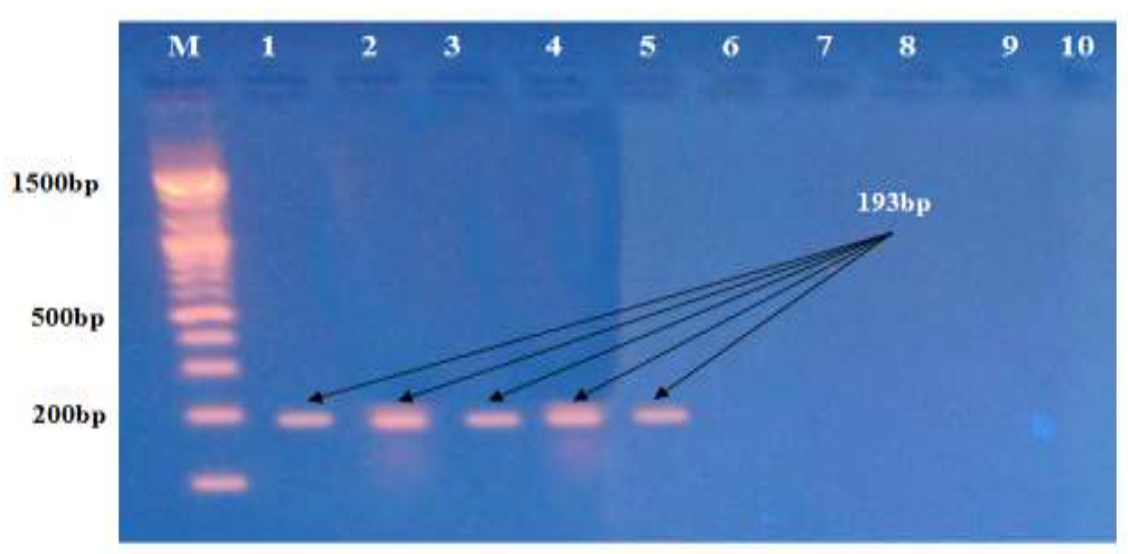

Figure (1): First run of nested PCR (amplification of 193bp) fragment of $B 1$ gene of $T$. gondii. M marker 100bp, 1-5 positive sample and other negative samples 


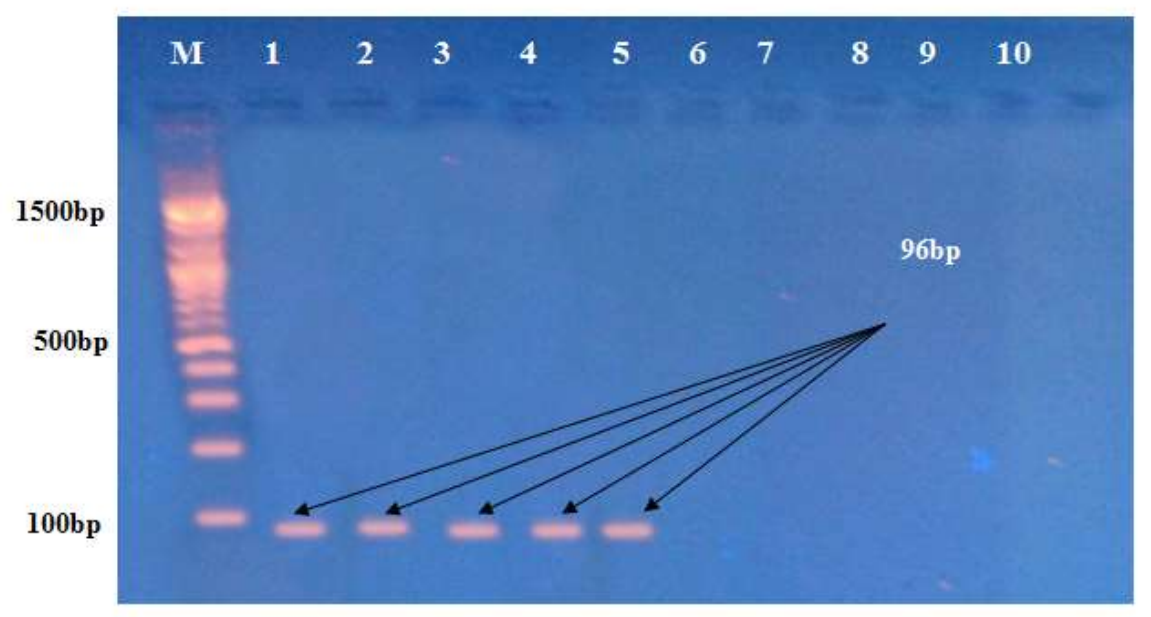

Figure (2): Second run of nested PCR (amplification of 96bp) fragment of $B 1$ gene of $T$. gondii .M marker 1-5 positive and others negative

Table (2): n PCR amplification for patients and control

\begin{tabular}{c|cc|cc|cc}
\hline PCR result & \multicolumn{2}{|c|}{ Patient } & \multicolumn{2}{c|}{ Control } & \multicolumn{2}{c}{ Total } \\
\cline { 2 - 7 } & No. & $\%$ & No. & $\%$ & No. & $\%$ \\
\hline $\begin{array}{c}\text { PCR } \\
\text { positive }\end{array}$ & 48 & $\mathbf{8 0 . 0 0}$ & 0 & 0.00 & 48 & 56.5 \\
\hline $\begin{array}{c}\text { PCR } \\
\text { negative }\end{array}$ & 12 & 20.00 & 25 & 100.0 & 37 & 43.5 \\
\hline Total & 60 & $100 \%$ & 25 & $100 \%$ & 85 & $100 \%$ \\
\hline $\begin{array}{c}\text { Chi- } \\
\text { square- } \chi^{2}\end{array}$ & --- & $13.82 * *$ & $\cdots$ & $15.75 * *$ & $\cdots$ & $5.48 *$ \\
\hline & & & & & \\
\hline
\end{tabular}

Toxoplasma gondii is compose, parasite protozoan intracellular that worldwide spreading. Humans Infection is commonly wanting incidental, but it ability apparent itself in a several form in cases of congenital toxoplasmosis and in immune compromised individuals( 10).In this study results of statical analysis the chi-square $\chi^{2}$ of patients have shown (13.82) and control (15.75) are significant in nPCR mean to high infection in Iraqi women .

Some studied presented that a single $T$. gondii parasite could be detected by PCR (8) agreement with this study. A top exposition to icrease rate of positive PCR results that the amplification of $B$ lgene may be due to samples containing DNA parasite but it no viable pathogens (11).

A highly sensitive and specific of PCR is in order to a single one can be detected in a clinical sample (5). Numerous studies were reported that parasitaemia could detect by PCR in a few weeks prior to the appearance of any clinical symptoms $(12,13)$. These advantages have proportional speed, A detect potential very low numbers of pathogens or may more precisely, particular sequences of nucleic acid of pathogens and the ability to strictly distinguish at the species or sub-species level (14).

Disclosure T. gondii by DNA with minimizes PCR the problems notable when employ serology or cultured based assays. It economize labor and time display the high advantages of sensitivity and specificity. Used PCR to demonstrate the existence of Toxoplasma in diverse clinical samples such brain, amniotic fluid and cerebrospinal fluid (CSF), lymph nodes, whole blood and aqueous humor (15). PCR is consider ultimate importance in diagnosing infection of T.gondii in cases of immunosuppressive therapy or in patients with AIDS (14). 
The abortive women with positive was found Toxoplasma DNA in 48 (80.00\%), this could be coincide to a very neoteric infection when serological leading to scanty production of immunoglobulin not detected by serology, or other explanation that those patients are not able to produce specific antibodies, representing a state of immunodeficiency. Molecular tests that could detect the presence of circulating parasites would be of extreme application in this scenario. A positive serological result is direct detection of T.gondii in blood or elucidate the presence of parasite leading to the primary diagnosis.

(16)

\section{References}

1. Weiss LM, Dubey JP. Toxoplasmosis: a history of clinical observations. Int. J.Parasitol.(2009); 39: 895-901.

2. Dupey JP. Toxoplasmosis: A waterborne zoonosis. Vet. Parasitol.(2004); 126: 57-72.

3. Pradhan S, Yadav R, Mishra VN. Toxoplasma meningoencephalitis in HIV-seronegative patients: Clinical patterns,imaging features and treatment outcome. Transactions of the Royal Society of Tropical Medicine and Hygiene. (2007); 101(1): 25-33.

4. Nagaty IM, Ibrahim KM, Abdel-Tawab AH, Hassan AE.Diagnosis of Toxoplasma gondii by ELISA and PCR mothers and their infants. J Egypt Soc Parasitol .(2009);39(2):625-32.

5. Guy EC, Joynson DHM. Potential of the polymerase chain reaction in the diagnosis of activeToxoplasma infection by detection of parasite in blood. J. Infect. Dis.(1995); 172: 319-322.

6. Chabbert E, Lachaud L, Crobu L, Bastien P.Comparison of two widely used PCR primersystems for detection of Toxoplasma in amniotic fluid, blood and tissues. J. Clin. Microbiol.(2004); 42:1719- 1722.

7. Jones CDN, Okhravi P, Adamson S, Tasker S. Lightman.Comparison of PCR detection methods for B1, $\mathrm{P} 30$, and $18 \mathrm{~S}$ rDN A genes of T.gondii in aqueous humor. Investigative Ophthalmol.

And Visual Science.(2000); 41(3): 634.

8. Burg JL, Grover CM, Pouletty P, Boothroyd JC. Direct and sensitive detection of a pathogenic protozoan Toxoplasma gondii by polymerase chain reaction. J. Clin. Microbiol. (1989); 27: 1787-1792.

9. Elisabeth C, Laurence L, Lucien C, Patrick B. Comparison of two widely used PCR primers systems for detection of Toxoplasma in aminotic fluid, blood, and tissues. J. Clin. Microbiol.(2004); 42(4): 1719-1722.

10. Badr M, Attia S, EL-SHerbiny W, EL Ebid A, Hefny H, Salem A. Genetic poly morphismes of Toxoplasma gondii from recently infected aborted egyoptan women. J. of the Egyptian Society of Parasitology.(2016); 46,1.

11. Wastling JM, Nicoll S, Buxton D. Comparison of two gene amplification methods for the detection of Toxoplasma gondii in experimentally infected sheep. J .Med. Microbiol.(1993); 38: 360-365.

12. Mimori T, Matsumoto $T$, Calvopina MH. Usefulness of sampling with cotton swab for PCR-diagnosis of cutaneous leishmaniasis in the New World. Acta. Trop.(2002);81(3):197-202.

13. Strauss-Ayali D, Jaffe VL, Burshtain O, Gonen L, Baneth G. Polymerase chain reaction using noninvasive obtained samples J. Infect. Dis.(2004);189(9):1729-1733.

14. Alfonso Y, Fraga J, Cox R. Comparison of four DNA extraction methods from cerebrospinal fluid for the detection of Toxoplasma gondii by polymerase chain reaction in AIDS patients. Med. Sci. Monit.(2008); 14: 1-6.

15. Savva D, Morris JC, Johnson JD, Holliman RE. Polymerase chain reaction for detection of Toxoplasma gondii. J.Med. Microbiol.(1990); 32,25-31.

16. Mahmood S, Hassani H, Zghair K. Detection of $B 1$ gene of Toxoplasma gondii in blood of pregnant andabortive women infected with this parasite. IRAQI J MED SCI.(2010);8 (3):42-48. 